\title{
EGY KISVÁROS HELYZETE AZ INFORMÁCIÓS KORBAN
}

\author{
(The position of a small town in the information age)
}

\section{BARSI BOGLÁRKA}

Kulcsszavak:

kisváros információs társadalom IKT

A szerzö tanulmányában egy kisváros helyzetét kívánja bemutatni az információs korban. Rávilágít arra, hogy habár az információs és kommunikációs technológiák segitenek a távolságok és térbeli akadályok legyözésében, nem jelentik a tér szerepének csökkenését. Az új technológiák felerösitették a korábban is létezö területi különbségeket, és tovább növelték a városok, elsősorban a nagyvárosok versenyképességi elönyeit.

A bemutatott kisváros mérete, mozdulatlan gazdasága nem teszi lehetővé az információs társadalom elönyeiböl való részesedést. A városi önkormányzat, a kulturális és oktatási intézmények kis költségvetésböl gazdálkodnak, nem jut elegendö forrás az informatikai fejlesztésekre. Sok helyen hiányzik a megfelelö szakember gárda is. Mindez megfelelö cselekvési stratégia nélkül a város további leszakadását eredményezheti.

\section{Bevezetés}

Az információs társadalomról szóló társadalomtudományi gondolkodás az 1990es évektöl került elötérbe (Drucker 1993; Stehr 1994; Castells 1996; 1997), de a jelenséget vizsgáló törekvésekkel már jóval korábban is találkozhattunk (Bell 1973).

Az információs társadalom közelebb hozza egymáshoz a régiókat, országokat és városokat. A konvergens információs és kommunikációs technológiák fejlesztése és bevezetése óriási hatással van a világ minden részén található különböző típusú és méretü szervezeti egységekre. Az információs társadalom sikerének egyik legkritikusabb ilyen egysége a város, mely akárcsak a többi entitás olyan új kihívásokkal néz szembe, mint a demokrácia új lehetőségei vagy az elektronikus kereskedelem. Az IKT (információ és kommunikáció technológiai) szektor megteremti a hatóságok számára jobb és költség-hatékony szolgáltatások nyújtásának, valamint a demokratikus folyamatok és a regionális gazdasági fejlődés megerősítésének lehetőségét.

Az elektronikus kommunikációs és információs technológia minden korábbi feltételezés ellenére sem ássa alá a városok helyzetét, fontosságát. Sőt mára nyilvánvalóvá vált, hogy az információs technológia és a város szoros, egymást kölcsönösen támogató kapcsolatban van. Ennek három fó oka:

- Az IKT szektor a már meglevő, magas hozzáadott értékű ipar és szolgáltatások mellé települ, meggyorsítva a város fejlődésének dinamikáját.

- A törékeny globális világgazdaság, a valamennyi ágazatban növekvő komplexitás és innovációs kockázat azt eredményezte, hogy az IKT oda települt, ahol 
megfelelő az „innovációs milio”, hogy biztosíthassa a folyamatos versenyképességet.

- Végül az IKT keresleti oldalát is a városok jelentik: mobil és vezetékes telefonhálózatot, számítógépes hálózatokat, internet szolgáltatásokat. Ennek fóbb okai: a nagy városok modernizációs kultúrája, a tőke koncentrációja, a relatíve magasabb elkölthető jövedelem, a nemzetközi orientációjú és transznacionális társaságok magas koncentrációja (Graham 2000).

Ezek a tényezők a nagyvárosok helyzetét erősítették (Barsi-Csizmadia 2001). Ráadásul a nagyvárosokban koncentrálódnak a fontos döntéshozók, és minden korábbi várakozás ellenére a személyes kapcsolatok fontossága egyáltalán nem csökkent. A személyes találkozók során ugyanis a kommunikációs folyamat például a hangszínváltozásokkal, mimikával és taglejtésekkel is gazdagodik. Az is bizonyított, hogy a problémamegoldás kreativitása és hatékonysága nagymértékben megnő a személyes kontaktusok gyakoriságának növekedésével (Sweeney 1987). Ha a személyes kapcsolat már létrejött, akkor az a továbbiakban már fenntartható a technológia eszközeivel (telefon, fax, e-mail), de a személyes kontaktus továbbra is a kommunikáció elsődleges fontosságú területe marad (Grimes 2000) Meier-Dallach ezt úgy fogalmazta meg, hogy az IKT-nek a „,rutin kontaktusok” terén van nagy szerepe, de nem helyettesitheti a „döntéshozó kontaktusokat” (Meier-Dallach 1998).

Nem véletlen az Internet tartalom elóállítók nagy területi koncentrációja sem (Tuomi 2001). Ugyanis az ilyen cégeknek elengedhetetlen a megfelelő információhoz és tudáshoz való hozzáférés, méghozzá az olyan tudáshoz, amely nehezen fejezhető ki digitális vagy szöveges formában. Ezt a problémát mutatja be Collins a tudományos információk átadásáról szóló tanulmányában (Collins 1975; 1987). Collins bemutatta, hogy gyakran szinte lehetetlen a tudományos tapasztalatot szimplán az eredmények leírásának elolvasásával megismételni. A leggyakrabban ehhez fizikai közelség és szituációs tudás szükséges.

A fent elmondottakból világosan következik, hogy a tereket áthidaló, távolságokat legyőző internet és információs technológia újratermelheti a városhálózatban ma is létezö versenyképességi különbségeket és szakadékokat.

\section{Módszertani megjegyzések}

A Zirc városról készített elemzés egy nagyobb kutatási projekt részeként született meg, melynek során a magyar városhálózat infokommunikációs jellemzőit vizsgáltuk (Grosz 2002). Az elvégzett klaszterelemzés eredményeként kialakított hat csoport közül ${ }^{1}$ Zirc a mozdulatlan városok csoportjába került. Ebbe a csoportba olyan kis- és középvárosok találhatók, amelyek az infokommunikációs szektor fejlődését tekintve a városhálózatban mozdulatlannak mondhatók. A csoporttagok mozdulatlanságát mutatja az is, hogy az odavándorlások és az elvándorlások között alig fedezhető fel különbség. A munkanélküliségi ráta az országos átlag körül mozog (6,5\%). A gazdasági szervezetek számához képest alacsonynak mondható az IKT ágazatban érdekelt vállalkozások aránya. 
A csoportból Zircet választottuk ki, mint mintavárost. A statisztikai adatok feldolgozása mellett 2002 januárjában mélyinterjúkat készítettünk a helyi önkormányzat, különböző intézmények és vállalkozások szakembereinek személyes megkérdezésével.

Legfontosabbnak tartottuk az önkormányzat munkájának, infokommunikációs törekvéseinek áttekintését, amit a polgármesterrel, jegyzővel, illetve az informatikai referenssel készített interjú során ismertünk meg. Itt tudakozódhattunk továbbá az önkormányzathoz kapcsolódó és az általa fenntartott intézmények, pl. általános iskolák helyzetéről. Lényeges információkat tudtunk meg a városi könyvtárak illetékes szakembereitől a látogatók informálódási szokásairól, a könyvtárban elérhető internet használatáról, fejlesztési tervekről, javaslatokról. A kamarai és vállalkozásfejlesztési irodák munkatársaitól a gazdasági szféra, hangsúlyozottan a kis- és középvállalkozások ellátottságát, illetve a vállalkozásokat segítő intézmények infokommunikációs szolgáltatásait szerettük volna megismerni. Ezen kívül interjút készítettünk az informatikai vállalkozások, internet szolgáltatók vezetőivel.

A településrendszert nagymértékü átalakulás jellemezte az elmúlt évtizedekben. A gyors ütemű városodási folyamat, mint az urbanizáció egyik megjelenési formája, eredményeként a városok száma az 1950. évi 54-ről az utóbbi mintegy fél évszázad alatt 252-re emelkedett. A különösen a nyolcvanas évektől felerősödő várossá nyilvánítási hullám következtében egyre inkább viszonylag kisebb népességszámú települések kaptak városi rangot; így a városhálózat közel 40\%-ában tízezernél kevesebben élnek. Zirc egyike ezen településeknek.

\section{IKT jellemzök}

Egy település infokommunikációs helyzetét alapvetően meghatározza a távközlési szektor helyzete. Zircen az ezer lakosra jutó távbeszélő állomások száma országos viszonylatban átlagosnak mondható. A kilencvenes években tapasztalható óriási fejlődés e kisvárost is jelentős mértékben érintette, 1995 és 2000 között közel hatszorosára emelkedett a távbeszélö-fövonalak száma, a lakásokban felszerelt vonalak számának növekedése pedig több mint tízszeres volt. Az üzleti vonalak aránya (1. táblázat) jóval meghaladja mind az országos, mind a csoportátlagot (42, illetve $70 \%-\mathrm{kal})$.

\section{TÁBLÁZAT}

A lakossági és üzleti távbeszélö fövonal ellátottság (Main phone lines per inhabitants and enterprises)

\begin{tabular}{lccc}
\hline & $\begin{array}{c}\text { Távbeszélö } \\
\text { fövonal } \\
(\mathrm{db} / 1000 \text { fö) }\end{array}$ & $\begin{array}{c}\text { Üzleti vonalak aránya az } \\
\text { összes távbeszélö } \\
\text { vonalon belül, \% }\end{array}$ & $\begin{array}{c}\text { Üzleti vonalak } \\
\text { száma, } \\
\text { db/vállalkozás }\end{array}$ \\
\hline $\begin{array}{l}\text { Zirc } \\
\begin{array}{l}\text { Csoport városai } \\
\text { (csoportátlag) }\end{array}\end{array}$ & 314,23 & 0,14 & 0,52 \\
$\begin{array}{l}\text { Összes város } \\
\text { átlaga }\end{array}$ & 291,04 & 0,08 & 0,38 \\
\hline
\end{tabular}

Forrás: T-STAR 2000 adatbázis, KSH. 
A vezetékes távközlési piac növekedésének fö motorját az ISDN (Integrated Services Digital Network) vonalak bekötési díjai jelentették elsősorban. A vezetékes telefon piacának mennyiségi növekedése ugyanis telítődik. A fejlődési alternatívát ezért a szolgáltatások minőségi fejlesztése jelentheti. Ezt irányozták elő a 2000-ben elindított ISDN kampányok. Az ISDN vonalak aránya 1999-ben az összes állomásból még csak 1,23 százalék volt, ami az országos átlagnak még a felét sem érte el. Az utóbbi félév azonban valószínüsíthetően nagymértékü fejlődést hozott, hiszen a helyi szolgáltató 2001-ben akciót hirdetett, melynek során az analóg vonal leadása esetén belépési díj nélkül ISDN vonalra cserélték a telefonvonalakat. Ezzel gyaníthatóan sokan éltek is. A mélyinterjú során megkérdezett intézmények mindegyikének ISDN vonal áll rendelkezésére, kevés az információnk azonban arról, hogy mennyi vonal van a lakosság tulajdonában. Annyi azonban bizonyos, hogy a jövő a gyors elérést, letöltést, adatforgalmat lehetővé tevő rendszerekben van, melyek természetesen a költségeket is csökkentik. Az Internet világával, lehetőségeivel megismerkedők a minőségi elérésre törekednek, elengedhetetlen számukra a nagyobb adatátviteli sebesség.

Míg a távközlési piac egyes óriásai esetleg a fogyasztók számára is kínálhatnak kedvezőbb megoldásokat a közeljövőben megélénkülő távközlési versenyben, arra vélhetően nem lehet majd számítani, hogy egyes városok érdekeinek, igényeinek megfelelő egyedi megoldások kialakításában részt vegyenek. A fejlesztésekbe könnyebben bevonható, kompromisszumkész partnerként ugyanakkor várhatóan jó eséllyel számíthatnak majd az egyes városok az ugyan kisebb fajsúlyú, de helyi székhelyü, illetve az adott régióra koncentráló szolgáltatókra. Zircen nincs helyi székhelyu" Internet-szolgáltató, de az elérhetö szolgáltatók, azaz Internetszolgáltatást nyújtó vállalkozások száma meghaladja mind az országos, mind a csoportátlagot. Az Internet-szolgáltatók több mint fele Budapesten van bejegyezve, a fövárost a megyei jogú városok követik (32\%), míg a többi város csekély súlyt képvisel.

A domain szerverek száma Zircen nagyon alacsony, mindössze 11 darab, ami messze alatta marad az országos átlagnak, de a csoportátlagnak sem éri el a felét, viszont pontosan megegyezik a csoportban mérhető medián értékével (a csoportba tartozó városok felében 11-nél kevesebb, felében 11-nél több domain szerver található) (2. táblázat). A szerverek száma általában összefüggést mutat a település általános gazdasági-társadalmi fejlettségével és a működő gazdasági vállalkozások számával, mivel a szerverek döntő többsége üzleti tevékenységhez kapcsolódik. Az átlagos fejlettségünek mondható Zircen tapasztalható alacsony szerverszám összefüggésben lehet azzal, hogy nincs elegendö sávszélesség a megfelelö szolgáltatás nyújtására, nem megfelelö az adatátviteli sebesség. Az ISDN vonalra való átállás 2001 végén indult meg, ADSL (Asymmetric Digital Subsciber Line) szolgáltatás még nem elérhető. 


\section{TÁBLÁZAT}

Internetes szolgáltatások, domain szerverek (Internet services, domain servers)

\begin{tabular}{lccc}
\hline & $\begin{array}{c}\text { Internetes szolgálta- } \\
\text { tási formák, db }\end{array}$ & $\begin{array}{c}\text { Internet szolgáltatást } \\
\text { nyújtó vállalkozások, } \\
\mathrm{db}\end{array}$ & $\begin{array}{c}\text { Domain } \\
\text { szerverek, db }\end{array}$ \\
\hline $\begin{array}{l}\text { Zirc } \\
\begin{array}{l}\text { Csoport városai } \\
\text { (csoportátlag) }\end{array}\end{array}$ & 1 & 13 & 11 \\
Összes város átlaga & 0,44 & 11,38 & 26,4 \\
\hline
\end{tabular}

Forrás: Budapesti Hírközlési Felügyelet, MTA RKK ATI.

Az informatikával és távközléssel foglalkozó cégek döntő többsége Budapest székhellyel müködik. A Zircen müködő feldolgozó-ipari ITK vállalkozások száma három, ami az összes gazdasági szervezet másfél százaléka, majdnem kétszerese a csoport átlagának, és az összes város átlagát is kismértékben meghaladja (3. táblázat).

3. TÁBLÁZAT

Gazdasági vállalakozások

(Businesses)

\begin{tabular}{lcc}
\hline & $\begin{array}{c}\text { Összes gazdasági } \\
\text { szervezet, db }\end{array}$ & $\begin{array}{c}\text { Feldolgozóipari ITK } \\
\text { vállalkozások, db }\end{array}$ \\
\hline Zirc & 204 & 3 \\
Csoport városai & 324,34 & 1,55 \\
(csoportátlag) & 699,9 & 2,84 \\
Összes város átlaga & & \\
\hline
\end{tabular}

Forrás: KSH Cég-Kód-Tár.

Zircen nincs kifejezetten informatikai képzést nyújtó középiskola, de az informatika oktatása nagy hangsúlyt kap a szakképző iskolában, ahol lehetőség van számítástechnikából különböző szintü OKI képzéseken való részvételre. Ennek oka valószínűleg az, hogy egy kisvárosban inkább az általános képzés nyújtása a cél, a speciális igények kielégítését a nagyobb, több közoktatási intézményt fenntartani tudó városok végzik. A Zirctől 20 km-re fekvő Veszprém megfelelő lehetőséget nyújt a kifejezetten informatika specializációt kereső diákok részére. Az általános iskolában már indítottak speciális számítástechnika képzést, tehát felismerték az informatikai képzés fontosságát.

\section{A helyi intézmények, szervezetek helyzete az információs korban}

Az információhoz való hozzájutást, elsősorban a városi, illetve megyei fenntartású közintézmények segíthetik elő. A megkérdezett intézmények helyzete nem túl kedvező, és többségük nem is remél az elkövetkezendő néhány évben javulást. Az intézményi vezetők többsége felismerte az információs korban rejlő új kihívásokat 
és lehetőségeket, de úgy véli, hogy a fejlesztést, a képzést vagy éppen nyilvános Internet-pont létrehozását anyagi helyzetük nem engedi meg. Ugyanakkor az elvégzett mélyinterjúk tanulsága az, hogy nagyon sok múlik az „emberi tényezőn”. A hozzáértő, elkötelezett vezetö sokat tehet a szervezet fejlesztése érdekében, megfelelő motivációt jelenthet a munkatársak számára. Ahol hiányzik a vezetői akarat, ott a megfelelő pénzügyi feltételek mellett sem várható infokommunikációs fejlesztés.

A városi polgárok nagy része szerint a legfőbb probléma a megfelelő szórakozási, kikapcsolódási kulturális lehetőségek hiánya. A legtöbben egy korszerủ múvelődési házat, mozit hiányolnak a város életéből, úgy vélik, hogy Zirc unalmas, szürke kisváros lett az elmúlt időszakban. A zirciek szerint a munkalehetőségek bővítése, az utak állapotának javítása, a bazilika felújítása, tehát a város „külső” képének rendezése a legfontosabb feladatok.

\section{Önkormányzat}

A város önkormányzatánál 41 köztisztviselö dolgozik. Jelenleg 28 számítógéppel rendelkeznek, melyek közül azonban csak három mondható korszerünek (Pentium II-es), a többi 486-os és Pentium I-es. A gépek nincsenek hálózatba kötve, csak az adócsoportnál lévő gépek müködnek helyi hálózatban. A számítógépeket elsősorban szövegszerkesztésre használják az alkalmazottak. Ennél magasabb szintü alkalmazásra elenyésző számban veszik igénybe a gépeket. Az Internet egyetlen gépről érhető el, ISDN vonalon keresztül. A szolgáltató (Vivendi Telecom Hungary) tavaly akciót hirdetett, melynek során az analóg vonal leadása esetén belépési díj nélkül ISDN vonalra cserélték a telefonvonalakat.

Az önkormányzatnál nem dolgozik külön informatikus, ezeket a feladatokat a városfejlesztési osztály vezetője látja el. Négy önkormányzati munkatárs szerzett ECDL vizsgát, egy alkalmazott rendelkezik számítógép kezelői vizsgával, tizenöten még a kilencvenes évek elején végeztek el egy 40 órás gépkezelői tanfolyamot.

Továbbképzésre 2000-ben 400 ezer forintot, 2001-ben már csak 140 ezer forintot fordított a hivatal. 2001-ben 2 millió forint szerepelt a költségvetésben informatikai fejlesztésre, amiből bővítették a gépparkot és szoftvereket szereztek be. A 2002-es költségvetésben is 2 millió forint szerepel, ez a költségvetés mintegy 0,2-0,3\%-a.

A nagyobb informatikai fejlesztések, gépek beszerzése azonban nem elégséges, csak szükséges feltétele a számítógép és Internet használat elterjedésének, az eközigazgatás irányába történő elmozdulásnak. Döntő fontosságú az emberek meggyőzése, a bürokratikus akadályok és megszokások legyőzése, a személyes vezetői elkötelezettség.

Oktatás, kulturális élet

Az információs társadalomhoz szorosan kötődik az oktatás, mivel az a tudás megszerzésén, naprakész voltán és használatán alapul. Az oktatásnak garantálnia kell, hogy mindenki hozzá tudjon férni ugyanahhoz a rendelkezésre álló információhoz. Az iskolák nagymértékben elösegithetik, hogy az új információhoz és kommunikációs technológiákhoz való hozzáférés a demokratizmus elvén érvényesüljön. Az oktatási rendszeren múlik az, hogy mindenki egyformán elsajátíthassa az információ 
felhasználásához szükséges módszereket, és ki tudja válogatni, rendszerezni és összegezni az adatokat, tényeket. Ezen kívül feladata, hogy felkészitse az embereket a nagy mennyiségü információ befogadására, az állandóan változó világ követésére (Varga 1998).

Az oktatás fejlesztésének sikere nagyban függ attól, hogy a helyi közösség szemében milyen értéket képvisel az oktatás. Az információs társadalomban az oktatásra kettős súly nehezedik. Egyrészt a jövő generációt fel kell készítenie az információtechnológia használatára, másrészt a mai, már dolgozó korosztályokat is tovább kell képeznie, hogy képesek legyenek az új technológiák használatára. Méghozzá nemcsak speciális informatikai képzésre van szükség, hiszen az informatika mindegyik szakmába többé-kevésbé beépült ma már. Mindez nem közömbös az egész társadalom szempontjából sem, hiszen az oktatás állapotán, a társadalom képzettségén függ egész további sorsa, ezt sok példa bizonyítja korunkban is. Ez az oktatás azonban meglehetösen költséges. De míg a felnőttek továbbképzése valószínủleg elég nagymértékben piacosítható, - a költségeket részben az oktatottakra, részben alkalmazóikra hárítva - a rendszeres iskolai jellegű oktatás (az általános iskolától az egyetemekig) csak nagyon kis mértékben, vagy egyáltalán nem fedezhető az oktatottak hozzájárulásából. Ennek fedezete csak állami, társadalmi támogatásból képzelhető el (Varga 1998).

Az Európai Unió felmérései bizonyítják, hogy miközben az információs és kommunikációs technikák a munka világában az elvártnál is nagyobb arányt képviselnek, vagyis átlagosan a munkahelyek 45\%-ában szükséges számítógéppel dolgozni (ez az arány kiugróan magas Dánia, Hollandia és Svédország esetében), az alkalmazottak azonban még az alapvető számítógépes ismereteknek sincsenek birtokában. (Mindössze 16\%-uk rendelkezik a munkája ellátásához szükséges jártasságokkal és készségekkel. Nem beszélve arról, hogy a távmunka - sok szempontból nagyon ígéretes - lehetőségei is csak megfelelő készségek birtokában vehetők igénybe. Pedig ezáltal egyre több olyan munkavállaló is munkához és jövedelemhez jutna, aki - fogyatékossága, a munkahelytől való nagy távolság vagy családi helyzete miatt - hagyományos munkahelyi körülmények között nem képes dolgozni [Mihály 2001].)

Az iskolarendszer megújítására kijelölt feladatok megvalósításához óriási változtatásokra van és lesz szükség. Az elvárások egy része ugyanis az iskolák eszközellátottságát, más része az oktatás tananyagtartalmát, illetve az alkalmazott módszereket, a harmadik a pedagógusképzés és -továbbképzés teljes intézményrendszerét érinti.

Zircen jelenleg négy oktatási intézmény müködik, egy zeneiskola, egy általános iskola és két középiskola. A két középiskola fenntartója a Veszprém megyei önkormányzat, a többi iskola a város kezelésében van. Az iskolák lehetőségei és eredményei még egy ilyen kis városon belül is nagyon különbözőek. A különbségek egyrészt az eltérő pályázati, anyagi lehetőségekből, másrészt a személyi feltételekből adódnak. 
Az alapfokú intézményrendszer az utóbbi években jelentős változásokon ment keresztül, mert 2000. augusztus 1-jétől a városban müködő két általános iskolát öszszevonták, azóta egy alapfokú tanintézmény található Zircen. Az iskolába 870 diák jár. A tantestület létszáma 76 fö. Az összevonás miatt az iskola több épületben, nehéz körülmények között müködik. Felismerve az új kihívásokat, az intézmény ebben az évben indította el az angol-számítástechnika programot. A speciális program keretében második osztályban kezdik el a számítástechnikát oktatni, heti három órában. A meghirdetett képzésre igen nagy volt az érdeklődés, jóval meghaladta a meghirdetett keretet. Azok a gyerekek, akik nem speciális képzésben vesznek részt, hatodik osztálytól kezdve tanulnak számítástechnikát, hatodikban heti egy, hetedik és nyolcadik osztályban heti két órában.

\section{1. ÁBRA}

Az egy számitógépre, illetve az Internet-kapcsolattal is rendelkező számítógépre jutó tanulók száma az általános iskolákban, 2001

(Students/ one computer and students/ one computer with Internet access in the primary schools, 2001)

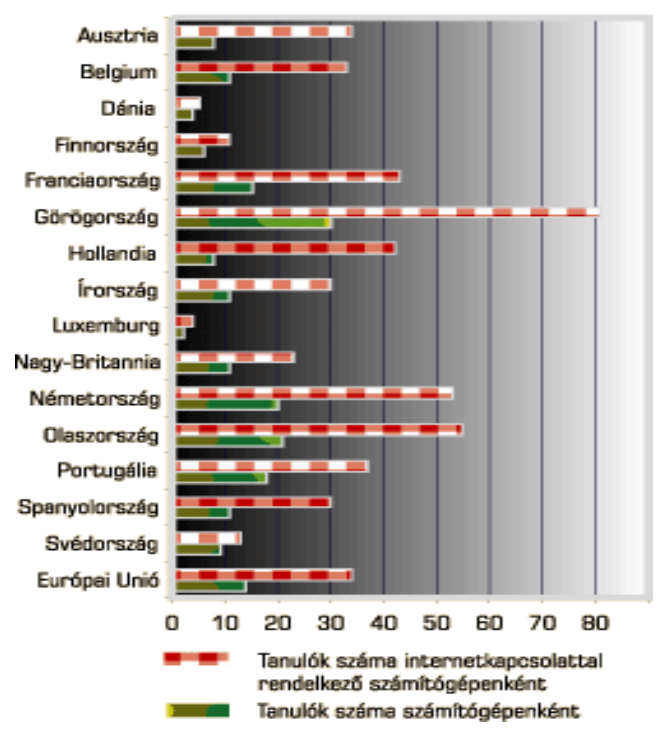

Forrás: Mihály 2001.

A számítógépes infrastruktúra helyzete meglehetősen lehangoló, az egy számítógépre jutó tanulói létszám mintegy háromszorosa az Európai Unió átlagának (1. ábra). Az iskola 24 számítógéppel rendelkezik, de ebből csak tizenkettő müködőképes, a többi egyelöre nem használható, többek között azért, mert nincsen meg a szoftverengedély. A géppark másik része (szintén tizenkét gép) nem az iskoláé, hanem egy számítógépes iskolát működtető vállalkozás tulajdonát képezi. Az intézmény bérleti díj nélkül biztosítja a tantermek használatát, cserében használhatják tanítási órákon a számítógépeket. Az együttműködés további előnye, hogy évente 
két tanár képzését a vállalkozás ingyenesen biztosítja. Ezzel a lehetőséggel az iskola él is. Minden évben beiskoláznak kettő-négy tanárt, akik középfokú képesítést szerezhetnek a másfél éves tanfolyam során. A megyei pedagógiai intézet szervezésében meghirdetett oktatás-informatikus képzésen eddig az iskola négy oktatója vett részt.

A gépek nincsenek hálózatba kötve, pedig ez az adminisztráció és a hatékonyabb tanári munka szempontjából is nagyon hasznos lenne, mert az iskola jelenleg hat különálló épületben müködik. Az iskola rossz számítógépes ellátottsága nem teszi lehetővé, hogy a gépek délután is a tanulók rendelkezésére álljanak, bár szakköri foglalkozásokat tartanak, a diákok a tanítási órákon kívül nem használhatják a gépeket. Ez azért elkeserítő, mert az otthoni számítógéppel nem rendelkező diákoknak nincs lehetőségük a tanórán elsajátított ismeretek gyakorlására, az Internet használatára, mely elősegítheti az információs szakadék újratermelődését a társadalomban. Zircen nincsen nyilvános Internet használati pont, ezért az iskola az egyetlen olyan hely, ahol lehetőség lenne az információs „szupersztrádára” csatlakozni.

Az iskola csak 2001 óta rendelkezik Internet hozzáféréssel, mivel nem került be a Sulinet programba. A vonalakat ISDN vonalra cserélték. Az egyik vonalat a Soros Alapítvány pályázatán nyerte az intézmény, így az Internet használatért csak egy nagyon kedvezményes dijat kell fizetniük. Az iskola több pályázaton is részt vett, de nyertes pályázat hiányában nem volt lehetősége a számítógépes infrastruktúra fejlesztésére. Az intézmény saját költségvetéséből nem tud informatikára áldozni, pedig az oktatás megfelelő színvonalának biztosításához szükséges lenne legalább egy komplett számítógép labor, 12 géppel, rendszerbe kötve, szoftverekkel felszerelve. A nyelvoktatásban kifejezetten hasznos lenne a gépek használata, különösen azért, mert külön nyelvi labort nem kívánnak kialakítani.

Az általános iskola értelmi fogyatékosokat is oktat, náluk már ötödik osztálytól van számítástechnika óra. A nemzetközi és hazai tapasztalatok azt mutatják, hogy az értelmi fogyatékosok képzésében az informatika nagy sikerrel alkalmazható, az igazgatónő szerint bámulatos eredményeket lehet a gépek alkalmazásával elérni.

A szaktanácsadást és a rendszergazdai feladatokat a zirci székhelyủ gazdasági társaság látja el. Ha csak kisebb javításokat kell elvégezni, nagyobb problémák nem merülnek fel, akkor ennek költsége évente 200-300 ezer forint.

Az általános iskolánál a problémát abban látják, hogy számitógépes infrastruktúra fejlesztésére az oktatási intézmények számára nagyon kevés pályázati lehetöség létezik, ha mégis van pályázati kiirrás, akkor ott általában csak egyetlen gépet lehet nyerni. Egy gép azonban nem oldja meg a problémákat, ráadásul így a géppark nagyon heterogén összetételü lesz.

Középfokú oktatási intézménnyel nem rendelkezik valamennyi kisváros, de Zircen két középiskola is müködik - a III. Béla Gimnázium és Mủvészeti Szakközépiskola valamint a Reguly Antal Szakképző iskola -, melyeket a Veszprém megyei önkormányzat tart fenn, mivel a város anyagi okok miatt átadta a fenntartási jogot. A két középiskola széles körü oktatási skálával rendelkezik, elősegítve azt, hogy a zirci 14-18 éves fiatalok otthonukban tanulhassanak. Persze a születésszám csökkenésével és a középiskolai képzési lehetőségek és formák növekedésével egyre inkább 
élesedett a harc a tanulókért, fokozódott a verseny a középiskolák között. Veszprém és Pápa középiskolái nagy vonzerőt jelentenek. Ugyanakkor a Zirc környéki bakonyi településekből nagy a bejárók aránya, de a speciális képzéssel rendelkező müvészeti szakközépiskolába Veszprém megyén kívüli tanulók is járnak. Mivel Zirc kis város, ezért két középiskolát nem tudna ellátni elég tanulóval. A két középiskola kollégiummal is rendelkezik, melyet 2001 decemberében adtak át (124 féröhelyes, jelenleg 110 diák lakik benne, ebböl 52 a gimnázium tanulója).

A gimnáziumban általános gimnáziumi osztály, német nemzetiségi tagozat, valamint müvészeti szakközépiskolai osztály müködik (díszítő festő és alkalmazott grafikus). Az iskolában jelenleg 10 osztály van, 285 tanulóval.

$\mathrm{Az}$ oktatásban részt vevö számitógépeket az Oktatási Minisztériumtól kapta a gimnázium, azóta nem sikerült új gépeket beszerezni. A 16 gép lehetővé teszi, hogy egyszerre egy egész osztályt lehessen informatikára oktatni, de ezek a gépek a $m u$ uvészeti képzésben felmerülő speciális igényeknek nem felelnek meg. Az is nyilvánvaló, hogy az oktatáson kívül rendelkezésre álló négy gép elavult, nem képes ellátni az iskolában felmerülő adminisztrációs feladatokat. Arra sincs elegendő forrás, hogy a diákok nyilvántartásához szükséges szoftvert beszerezzék. Arra pedig szinte nincs is lehetőség, hogy a tanárok rendszeresen használják a számítógépeket, mivel a könyvtári és a gazdasági feladatokat segítő gépen kívül tulajdonképpen nem áll rendelkezésre szabad kapacitású gép. Márpedig a jövő nem egyszerüen a számítógép használatának oktatása, hanem a számítógépnek, multimédiának a megjelenése az oktatási folyamat egészében. De, ha a tanár nem tudja a gépet rendszeresen használni, akkor erre nincs esély.

A gimnáziumban a diákok a kilencedik osztályban tanulnak heti két órában informatikát, a szakközépiskolai osztályokban mindegyik évfolyamon oktatnak számítástechnikát, hiszen a grafikusoknak elengedhetetlenül szükséges a számítógépes alkalmazások ismerete. A gépeket a tanórán kívül is lehet használni, reggel hét és nyolc között, és délután is. Az informatika szakos tanárok tartanak ügyeleti órákat is, ilyenkor a diákok szakmai segítséget kérhetnek.

Internet kapcsolattal, melyet a Sulinet program keretében kapott az iskola, 19 gép rendelkezik. A tanároknak nincs külön e-mail címük, csak az iskola rendelkezik e-mail címmel.

Az intézmény folyamatosan pályázik a számítógépes infrastruktúra fejlesztése és új szoftverek vásárlása érdekében, de eddig még nem volt sikeres pályázatuk. A müvészeti szakközépiskolai képzés beindításával különösen nagy szükség lenne egy új számítógépteremre, korszerü számítógépekre és szoftverekre.

A szakiskola oktatási profilja igen szerteágazó, ${ }^{2}$ diákjainak száma 560. Az intézmény úttörö szerepet vállalt az informatikai képzésben, hiszen már nyolc évvel ezelött bevezették a számítástechnika oktatást, és azt azóta is minden szakmában oktatják. Erre olyan nagy óraszám áll rendelkezésre, hogy az lehetővé teszi az operátori vizsga megszerzését. A vizsgát az iskola szervezi meg. Ezzel a lehetőséggel a diákok mintegy fele él is. Ha valaki ECDL vizsgát szeretne tenni, akkor az intézmény hív vizsgabizottságot. Az ECDL vizsgáztatást lehetővé tevő engedély ugyanis 
túl sokba került volna, és nem lett volna elegendő jelentkező ahhoz, hogy gazdaságos legyen.

Az iskolában középfoku szoftverüzemeltetöi képesitést is lehet szerezni érettségi utáni egy éves képzés keretében. A tapasztalatok azt mutatják, hogy a diákok inkább kiegészítő képzésként végzik el, tehát kevés az olyan, aki ebben a szakmában akar elhelyezkedni. Valamilyen más képzettség mellé szerzik meg, vagy sikertelen felvételi vizsga esetén kívánják hasznosan eltölteni a következő felvételi időszakig rendelkezésre álló egy évet. Az igazgató véleménye szerint téves elképzelés, hogy mindenkinek informatikusnak kell lennie. Mindenkinek azt kell megtanulnia, hogyan könnyítheti meg a munkáját a számítógép használatával (információszerzés, könyvelés, gépnyilvántartás vezetése).

Az intézmény öt számitástechnika teremmel rendelkezik, melyekben 15-20 gép van. Minden gép rendelkezik Internet csatlakozással. Ezek gyakorlatilag bármikor rendelkezésre állnak. Egy terem ugyanis folyamatosan nyitva van, ahol biztosított a felügyelet, tehát hozzáértő tanár segít, ha probléma vagy kérdés merül fel. A kollégiumban is van egy olyan számítógépterem, ami bármikor a diákok rendelkezésére áll.

1997-ben a Soros Alapitvány Közoktatási programján nyert az iskola, ez lehetövé tette $C^{3}$-on ${ }^{3}$ keresztül a bérelt vonalas Internet hozzáférést. A Sulinet program aztán átvette a szolgáltatást, de így elveszett a korábban meglévö gyors kapcsolat. Az adatátviteli sebesség $56 \mathrm{kB} / \mathrm{sec}$, ami nem elegendő már. Az a sávszélesség és kapacitás, amit a minisztérium biztosít, hét-nyolc gépnél tökéletesen müködik, olyan nagy gépállománynál azonban, amellyel az iskola rendelkezik, már látványosan lelassul a hozzáférés.

Az intézmény rendelkezik már ISDN vonalakkal, és azt szeretné elérni $a z$ Oktatási Minisztériumnál, hogy tegye lehetővé a $64 \mathrm{kB} / \mathrm{sec}-r e$ való áttérést. Az iskola a pénzügyi tranzakciókat számítógépen bonyolítja a bankkal, ezért is elengedhetetlen egy nagyon biztos vonal. Az is probléma, hogy a számítógépek amortizációja gyors, három év alatt gyakorlatilag nullára íródnak, ezért akik régebben kaptak gépeket a minisztériumtól, vagy pályázat révén jutottak azokhoz, már elavult gépekkel rendelkeznek. Az állomány frissitésének lehetöségét kellene megteremteni, vagyis hogy az elavult gépeket felújitsák. Az nem elvárás, hogy a teljes cserét biztosítsák, de szükség lenne arra, hogy legalább egy részéhez forrást nyújtsanak. Az intézmények nincsenek olyan helyzetben, hogy ezt önállóan megtegyék, különösen egy gimnázium. Pedig a frissítésre szükség van, hiszen bizonyos szoftvereket nem lehet a régebbi típusú gépeken használni.

Négy hálózat müködik az intézményben (Novell és NT). Négyböl kettőhöz férnek hozzá a tanulók, a másik kettő közül az egyik egy gazdasági rendszer, a másik pedagógiai rendszer. A tanmühely az oktatási épülettől viszonylag messze helyezkedik el, ott is van egy hálózat. A jövőbeli tervek között szerepel a rendszerek összekötése. Jelenleg az összekapcsolás előzetes költségvetését készítik.

A számítógépek, rendszerek fejlesztésére, karbantartására nagyon sok pénzt fordítanak. Az ehhez szükséges pénzt általában a szakképzési keretböl különítik el, illet- 
ve folyamatosan pályáznak. A hardverre évente 8-12 millió forintot, a szoftverekre évente másfélmillió forintot forditanak.

A tanárok rendszeresen használják a számitógépet és az internetet, minden tanár saját e-mail címmel rendelkezik. E nélkül elképzelhetetlen lenne a munka az iskolában, mivel a tanulói nyilvántartás, az összes adat, statisztika, osztályzatok csak a számítógépen elérhetők. Az igazgató nagy hangsúlyt helyez arra, hogy a tanárok és a diákok is megfelelö módon tudják használni a számítógépeket és az ehhez kapcsolódó eszközöket, ezért minden tanárnak kötelezö volt valamilyen számítástechnikai képesitést szereznie, így a tantestület minden tagja legalább operátori vizsgával rendelkezik. Talán a szakmai tanárok kicsit többet használják a számítógépeket, valószínüleg azért, mert több az alkalmazási lehetőségük. A közismereti órákon is alkalmaznak számítógépeket, leginkább nyelvórákon, de például a földrajz órákat is sokkal szemléletesebbé teszi a számítógép használata. A nyelvoktatáshoz szükséges programot az intézmény megvásárolta, és két termet fel is szereltek vele.

A tanítást tovább színesíti az is, hogy az iskola rendelkezik két projektorral is. Az iskolának van saját honlapja, de müködtetésére jelenleg az informatika tanároknak nincs elegendö kapacitása. Munkaügyi akreditációja is van a szakiskolának, rendszeresen foglalkoznak felnőtt képzéssel. Évente két-három tanár jár valamilyen informatikai képzésre, hogy saját tantárgyuk oktatásában alkalmazni tudják a számítógépeket.

Nagy probléma a szakiskolában, hogy nincs rendszergazdai státusz. A legtöbb iskolában az oktatás-technikus látja el a rendszergazda feladatait is, de nagyon nehéz olyan embert találni, aki az alacsony fizetés ellenére hajlandó ezt a munkát elvállalni. Ezért a vizsgált intézményben, akárcsak a többi iskolában, a számítástechnika tanár vagy tanárok külön megbízás alapján látják el ezeket a feladatokat. Ilyen nagy gépállománynál azonban már szükség van külső vállalkozás igénybevételére is, mely elvégzi a gépek és a hálózatok karbantartását. De sajnos ez nem a legjobb megoldás, mert néha sokat kell várni olyan egészen kis problémák esetén is, amit egy rendszergazda gyorsan orvosolni tudna.

Az iskola rendszeresen eredményesen pályázik. Decentralizált szakképzési pályázatból történt a hálózat utp-re állítása. A kollégiumi komplett számítógéplabort a Veszprém Megyei Munkaügyi Központ pályázatán nyerte az iskola. Ez 12 gépet jelent hálózatba kötve. 30 gépet nyertek a Világbank pályázatán. Az egyik projektort is pályázati forrásból vásárolták.

A Gábor Dénes Föiskola a 2002-2003-as tanévtöl informatikus mérnök képzést kíván indítani Zircen (müszaki informatika és gazdasági informatikus szakokon) távoktatási formában (a képzési idő 8 félév). A föiskola konzultációs központja a szakiskola lesz.

A Zirci Városi Könyvtár ${ }^{4}$ jelenleg egy darab számítógéppel rendelkezik, Internetkapcsolat nélkül, pedig arra az intézményben nagy szükség lenne. A könyvtári állomány számítógépre vitelét már elkezdték egy szoftver segítségével, ahhoz azonban, hogy a számítógépes könyvtári katalógus valóban müködjön, kb. egy millió forintos beruházásra lenne szükség. 
A könyvtár azonban igen kicsi költségvetésből gazdálkodik (2001-ben az összes kiadás 7,7 millió forint volt, ebből a bér és járulékai 4,5 millió forintot tettek ki), így technikai eszközök beszerzésére, azok fejlesztésére nem sok lehetőség marad. Ezeket az eszközöket pályázatok útján tudják csak megvásárolni.

$\mathrm{Az}$ intézmény nyert az Informatikai Kormánybiztosság SZT-IS-2-es pályázatán, az interjú készítésekor folyt a szerződéskötés, melynek eredményeként hat multimédiás számítógépet tudtak vásárolni, megtörténhetett a hálózat kiépítése, bérelt vonal beszerelése. A könyvtár dolgozói közül ketten elvégzik az „Internet használat könyvtári környezetben" tanfolyamot. Ezek után lehetőség lesz arra, hogy hatvan ember 1000 forintos regisztrációs dij befizetése után téritésmentesen vegyen részt egy 20 órás tanfolyamon, melyre nagyon nagy az érdeklődés. A pályázat ugyanis azt is lehetővé teszi, hogy a könyvtár egy évig ingyenes Internet hozzáféréssel rendelkezzen, és a könyvtárlátogatók részére is lehetöség lesz ingyenes Internet használatra. Természetesen a könyvtár vezetői az egy év lejárta után is szeretnék biztosítani az Internet használatot, de egyelöre nem tudják, hogy milyen forrásból fogják azt finanszírozni. Az intézmény ugyan tagja a HUNGARNET-nek, ami nagyon kedvezményes Internet előfizetést tesz lehetővé, de a könyvtár szerény anyagi helyzete még az évi körülbelül 200 ezer forint kifizetését sem teszi lehetővé, hiszen könyvvásárlásra is alig jut forrás.

Már az IKB pályázat előtt is folyamatosan gondolkodott a könyvtár igazgatója azon, hogy milyen módon lehetne nyilvános Internet pontot létrehozni, mivel nem volt olyan nap, hogy ne kerestek volna a könyvtárban internetezési lehetőséget, hiszen Zircen nincsen nyilvános Internet hozzáférési lehetőség. De forráshiány miatt erre eddig nem volt lehetőség. A tapasztalatok azt mutatják, hogy kisebb településeken ráfizetéses a könyvtárakban a nyilvános Internet használati lehetőség biztositása. Az internetet ugyanis elö kell fizetni, attól függetlenül, hogy aztán azt mennyien használják, a gépeket karban kell tartani, javítani kell. Ahhoz, hogy ne legyen vesztesége a könyvtárnak, körülbelül havi 40 ezer forint bevételre lenne szükség.

A művelődési házban két ember dolgozik főállásban, a meglehetősen elhanyagolt állapotú épületben. Egy számítógépük van Internet kapcsolattal. Az internetet informális úton használhatja, aki a művelődési házhoz fordul, a telefondíjat kell megfizetnie, de akkor félbe kell szakítani a munkát. Tehát valódi információs, Internet pont itt sem áll rendelkezésre. A művelődési házban nyilvános pont kialakítását nem tervezik, erre nem látnak igényt. Úgy vélik, hogy az iskolában a diákoknak lehetőségük van az Internet használatára, és a könyvtárban is hamarosan elérhetö lesz majd a világháló.

Vállalkozások

A vállalkozásfejlesztési alapítvány tapasztalata szerint az igazán kisvállalkozóknak és egyéni vállalkozóknak általában nincsen számítógépük, még kevésbé Internet kapcsolatuk. Ez abból is látszik, hogy a tanácsadásra érkező vállalkozók a pályázati anyagok letöltését mindig kérik, alig van olyan, aki azt mondja, hogy otthon is le 
tudja azt tölteni. Sőt az is gyakran előfordul, hogy az iroda ír és fogad e-maileket a vállalkozók nevében. Inkább a nagyobb, 10-15 alkalmazottat foglalkoztató cégeknek, illetve szellemi tevékenységet folytató vállalkozásoknak van számitógépük és Internet-hozzáférésük.

Zircen két nagyobb informatikai vállalkozás müködik. Az egyik szoftverfejlesztéssel, hálózat és hardvertelepitéssel, rendszerfelügyelettel foglalkozik. Míg időben a legtöbb ráfordítást ez utóbbi jelenti, pénzügyileg a hálózattelepítések a legjelentősebbek tevékenységükben. (Ennek elsősorban a hálózati elemek jelentős ára az oka.) Ügyfeleik elsősorban közintézmények és termelö vállalatok, a lakossággal nem állnak közvetlen kapcsolatban, a céget, tevékenységét nem is hirdetik ügyfélkörükön kívül. A cég „kemény magját” négy-öt fö alkotja, a szoftverfejlesztés és más feladatok azonban gyakran indokolják további résztvevook bevonását a munkákba, így általában tíz-tizenöt fövel dolgoznak. A cég rendelkezik bejegyzett domain névvel, ezen a lapon azonban csak ügyfeleikkel tartják a kapcsolatot, mások számára nem érhető el rajta szolgáltatás.

Két jelentősebb, pillanatnyilag futó projektjük, melyeket az intézmények pályázati forrásokból valósítanak meg, egy pápai általános iskola valamint a zirci Reguly Antal Szakiskola kollégiumának hálózattelepítése. Ez utóbbi milliárdos nagyságrendủ projekt, ahol a munkát végző fővállalkozótól kapják majd feladataikat.

A cég vezetöje úgy véli, hogy hátrányos számukra a zirci informatikai infrastruktúra fejletlensége. A hálózati elérhetöség javulásával könnyebben nyithatnának a lakosság felé is. Jelentős lépés lenne, ha a Vivendi megoldaná az ADSL kapcsolatok létesítését a településen. Emellett a cég életében meghatározó változást hozhatna az is, ha a helyi kábeltévé egészének csilllagpontúsítása révén megindulhatna a kábeles Internet-szolgáltatás is. Ez esetben szívesen jelennének meg lakossági Internet-szolgáltatóként is. A kábeltelevízió tulajdonosa hosszú távon tervezi is az Internet-szolgáltatás beindítását. A város gyakorlatilag egy utca kivételével részese a kábelhálózatnak, ráadásul annak fele csillagpontos, tehát alkalmas Internet szolgáltatás nyújtására, bár a lakosság irányából erre kifejezett igény még nem merült fel.

A kábelen keresztüli szolgáltatásnak pedig igen sok elönye van a felhasználó szempontjából. A kábeltévés kapcsolat folyamatos, a szolgáltató és a felhasználó közötti távolság nem mérvadó. Csak az számít, hogy az adott kábelszakaszhoz a szolgáltató hány felhasználót kapcsol. A kábelszolgáltatók ezért „információs csomópontokat" hoznak létre, és a felhasználószámnak megfelelően növelik azok kapacitását. Így átlagos kihasználtság esetén biztonságosan 300-500 kB/sec közötti letöltési és $128 \mathrm{kB} / \mathrm{sec}$ feltöltési sebességet tudnak biztositani, viszont, ha a felhasználók mind egyszerre használják nagy mennyiségü adat le-, illetve feltöltésére a kapcsolatot, akkor ez a sebesség csökkenhet. Nincs szükség telefonvonalra, a szolgáltatás havi fix dijas (jelenleg havi 10 ezer forint körüli összegért vehetö általában igénybe). Mivel az Internet kapcsolat mindig élö, különféle lifeline szolgáltatásokat lehet elérni, például vasúti menetrendeket, naprakész közlekedési információkat, híreket, időjárási információkat. 
A másik vállalkozás számitástechnikai hardver és szoftver értékesitésével, hálózatépitéssel, rendszerkarbantartással, rendszerfelügyelettel foglalkozik. Elsősorban vállalatokkal, másodsorban közintézményekkel állnak kapcsolatban. Az ügyfelektől körülbelül 10 millió forintig terjedő megbízásokat kapnak. Foglalkoznak lakossági ügyfelekkel is, számukra elsősorban számítógépeket értékesítenek és szervízelnek. A cég három alkalmazottat foglalkoztat, akik elsősorban Veszprém környékiek.

Zirc város önkormányzatával 1989 óta állnak kapcsolatban. Az együttmüködés elsősorban az önkormányzat irodai munkáját elősegítő gépek és szoftverek üzembeállítására, fenntartására korlátozódik. Noha felmerült már a lehetősége egy önkormányzati internet szerver létrehozásának, amellyel megoldható lenne az önkormányzat és a vele kapcsolatban álló intézmények, cégek kommunikációjának elektronikussá tétele, ennek megvalósítására azonban konkrét terv még nincs. A Bt. azonban szívesen venne részt ilyen munkában.

\section{Városi honlap}

A város rendelkezik saját honlappal (http://www.zirc.hu/) (2. ábra), de az fejlesztésre szorul, utoljára 2000-ben volt frissítve. Aktuális információk, programajánlatok nincsenek a honlapon, csak egy rövid városi ismertető, a legfontosabb intézmények elérhetősége és a település legjelentősebb nevezetességeinek rövid, fényképes bemutatása szerepel. Egyébként semmilyen más információ nem hozzáférhető, sem gazdasági (például a város gazdasági helyzete, legfontosabb cégek, foglalkoztatottság), sem turisztikai adatok (szálláshelyek, városba látogató turisták száma, nincs térkép a városról). Nem érhető el az önkormányzat költségvetése, megvalósított programok, beruházások, pályázati lehetőségek stb. Az oldal tehát meglehetősen hiányos, kevés a hozzáférhetö információ.

2. ÁBRA

$A$ város honlapja

(Homepage of the town)

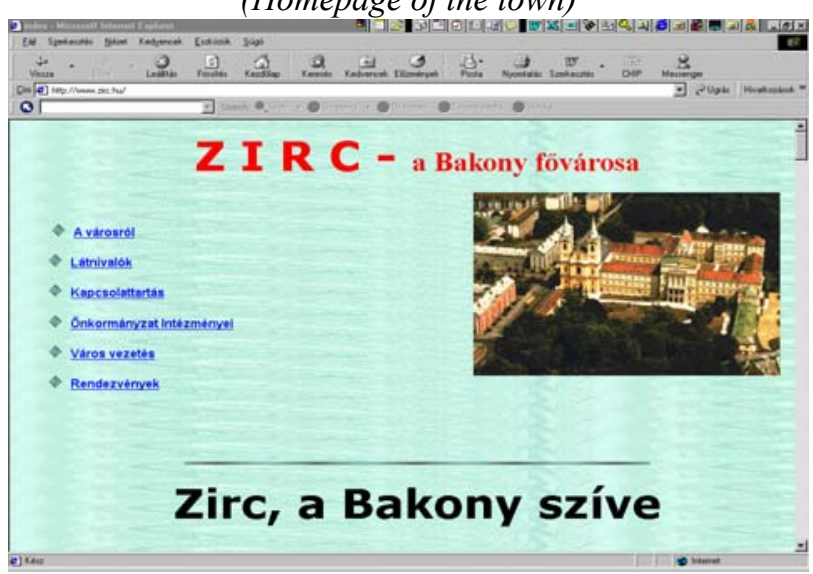

Forrás: http://www.zirc.hu/ 
2002-ben az önkormányzat pályázatot adott be az Informatikai Kormánybiztossághoz, az SZ-IS-8 pályázati felhívásra, az „Önkormányzatok internetes aktivitását biztosító eszközök és szolgáltatások támogatása" címen. Sikeres pályázat esetén várható a honlap jelentős megújítása.

A település egyes intézményei rendelkeznek internetes megjelenéssel saját honlapon, mint például a Bakonyi Természettudományi Múzeum (http://www.bakonymuseum.hu/), vagy a Hotel Szépalma (http://www.szepalma.hu/). Célszerü lenne azonban, ha az összes Zirccel kapcsolatos információ (gazdaság, turizmus, önkormányzati hírek, helyi programok, látnivalók) egyetlen honlapon megtalálható lenne, mert jelenleg nagyon nehéz interneten keresztül információt gyüjteni Zirc életéröl.

\section{Összegzés}

Zirc infokommunikációs helyzetét megvizsgálva világosan láthattuk, hogy a kisvárosok helyzete - néhány kivételtől eltekintve - nem túl kedvezö. Az önkormányzatnak egyelőre nincs lehetősége túlzott mértékü informatikai fejlesztésre. A város költségvetésének egyelőre csak igen kis hányadát képes informatikai fejlesztésekre fordítani, hiányzik a megfelelő motiváltság is az önkormányzat munkatársainak körében. A kulturális intézmények helyzete is kedvezőtlen, kis költségvetéssel, mindennapi problémákkal küszködnek. A könyvtár ugyan nyert hat multimédiás számítógépet, de az Internet-hozzáférés hosszú távú fenntarthatósága kétséges. Az oktatási intézmények helyzete nagyon különböző. Az általános iskola és a gimnázium szerényebb számítógépes parkkal rendelkezik, kevesebb pályázati forrás áll rendelkezésükre. A szakiskola számítógépes ellátottsága az országos átlagot jóval meghaladó, rendszeres, nagyobb összegü pályázati forrás biztosított a fejlesztésre. $\mathrm{Az}$ eltérő lehetőségeknek azonban csak az egyik oka a pályázati lehetőségek és források különbsége. A másik, legalább ennyire fontos ok az iskola vezetőségének elkötelezettsége és hozzáértése.

Az új technológiák és az információs társadalom megjelenése tehát egyáltalán nem jelentette a tér szerepének csökkenését. Ellenkezőleg. Minél kevésbé könnyebb áthidalni a térbeli akadályokat, annál fontosabbá válik a téren belül található régiók vagy települések eltérő mivolta, egyedi jellemzői, sajátosságai, tőkevonzó képessége.

Továbbra is fontos telephely-választási tényezö marad a környezet, az emberi eröforrás, a megfelelö kutatási kapacitás, a helyi gazdaság dinamikája és innovációs jellemzői. Az IKT tehát az egyes régiók közötti komparatív előnyök újraértékeléséhez vezet. Az egyes régiók között igen élessé válik a verseny, és csak korlátozott számú régió képes arra, hogy megfelelő döntéshozó és tudás-csomópont lehessen a technológia-alapú hálózatban. 


\section{Jegyzetek}

${ }^{1}$ Regionális központok csoportja, megyeszékhelyek és térségi központok, aktív kis- és középvárosok, üdülővárosok, mozdulatlan városok, leszakadó városok.

2 A következő szakmákat oktatják a szakiskolában: szállítmányozó, gépésztechnikus, gépjármü üzem technikus, logisztikai és szállítmányozói ügyintéző, középfokú szoftverüzemeltető, géplakatos, esztergályos, szobafestő, kőműves, asztalos, vendéglátós eladó, gyorsétkeztetési eladó, élelmiszer és vegyiáru kereskedő, falusi vendéglátó képzés (világ banki képzés), női ruhakészítő.

${ }^{3}$ A C ${ }^{3}$ Kulturális és Kommunikációs Központ Alapítvány célja az új tudományos-technológiai eredmények, felfedezések kulturális alkalmazásának, kreatív használatának, innovatív mủvészeti lehetőségeinek kutatása, fejlesztése, támogatása; új projektek létrehozása, művészeti, tudományos, kommunikációs, oktatási és kulturális programok kezdeményezése, megvalósítása és támogatása.

${ }^{4}$ A könyvtárnak jelenleg 1500 beiratkozott olvasója van, ami a város méretéhez viszonyítva igen szép szám. A könyvtári állomány nem olyan nagy, kb. 35-38 ezer kötet. Évente kb. 40 ezer kötetet kölcsönöz ki a kb. 5000 látogató.

\section{Irodalom}

Barsi B.-Csizmadia Z. (2001) Egy nagyváros helyzete az információs társadalomban. - Tér és Társadalom 2. 147-172. o.

Bell, D. (1973) The Coming of Post-Industrial Society. A Venture in Social Forecasting. Heineman, London.

Castells, M. (1996) The Information Age: Economy, Society and Culture: Volume I: The Rise of the Network Society. Blackwell Publishers, Cambridge.

Castells, M. (1997) The Information Age: Economy, Society and Culture: Volume II: The Power of Identity. Blackwell Publishers, Cambridge.

Collins, H.M. (1975) The seven sexes: a study in the sociology of a phenomenon, or the replication of experiments in physics. - Sociology. 9. 205-224. o.

Collins, H.M. (1987) Expert systems and the science of knowledge. - Bijker, W.E.-Hughes, T.P.-Pinch, T. (eds.) The Social Construction of Technologocal Systems: New Dimensions in the Sociology and History of Technology. MIT Press, Cambridge. 329-438. o.

Drucker, P.F. (1993) Post-Capitalist society. Harper Business, New York.

Graham, S. (2000) Bridging Urban Digital Divides? Urban polarization and Information and Communications Technologies (ICT): Current Trends and Policy Prospects. Backgorund paper for the United Nations Centre for Human Settlements (UNCHS), New York.

Grimes, S. (2000) Rural areas in the information society: diminishing distance or increasing learning capacity? - Journal of Rural Studies. 16.13-21. o.

Grosz A. (2002) A magyar városok infokommunikációs típusai. - Dőry T.-Grosz A. (szerk.) Az információhoz való hozzájutás társadalmi és földrajzi különbségei Magyarország városhálózatában. 137. sz. Közlemény, MTA RKK Nyugat-magyarországi Tudományos Intézet, Győr.

Meier-Dallach. H.P. (1998) The end of regions. - Hetland, P.-Meier-Dallach, H.P. (eds.) Domesticating the World Wide Webs of Information and Communication Technology. European Commission, Luxemburg. 283-304. o.

Mihály I. (2001) Korszerü információs és kommunikációs technikák az Európai Unió iskoláiban. http://www.oki.hu/cikk.asp?Kod=2001-10-vt-Mihaly-Korszeru.html

Stehr, N. (1994) Knowledge Societies. Sage, London.

Sweeney, G.P. (1987) Innovation, Entrepreneurs and Regional Development. Frances Pinter, London.

Tuomi, I. (2001) From Periphery to Center: Emerging Research Topics on Knowledge Society. TEKES, Helsinki.

Varga Cs. (szerk.) (1998) Zöld könyv az információs társadalomról Portugáliában. Országos Műszaki Fejlesztési Bizottság, Országos Rádió és Televízió Testület, HÉA Stratégiakutató Intézet, Budapest. 


\section{THE POSITION OF A SMALL TOWN IN THE INFORMATION AGE}

\section{BOGLÁRKA BARSI}

The author is aiming at presenting the position of a small town in the information society. Although the information and communication technologies help to overcome the spatial barriers, do not mean the decreasing role of space or the end of geography. The new technologies intensified the former existing spatial differences, and increased the competitive advantages of towns, primary large towns and cities.

The small size and stagnant economic position of the presented town do not make it possible to share the advantages of the information society. As a consequence of the small budget of the local government, the cultural and educational institutions there are not enough resources for technology development and for recruitment of experts. Failing an adequate action programme the town will lag behind. 